\title{
Trends of Public and Private Investment in Indian Agriculture: An Inter State Analysis
}

\author{
Dr. Poonam Singh \\ ICSSR Doctoral Fellow, GIDS, Lucknow \& Assistant professor, \\ Dept of Economics SRS Girls PG College, BareillyUttar Pradesh,India
}

\begin{abstract}
This paper deals with the analysis of trends in investment in Indian agriculture, with specific emphasis on the period of economic reforms. Analysis with investment series has confirmed deceleration in public investment both at national and state level. There are undeniable evidences of decline in investment in real terms after the eighties. Public investment in agriculture began to decline in the 1980s, In state level analysis, declining trend of public investment in real terms in most of the states also has been reported. The falling public investment in agriculture during the 1980 was mainly because of a large proportion of the resource flows to the agriculture sector going in to current expenditure on subsidies for fertilizers, irrigation, electricity, credit and other agricultural inputs, rather than investment, according to many scholars.

The reform process in India significantly weakened the structural support through declining public investment "in" agriculture as well as "for" agriculture. As part of fiscal reforms, major input subsidies were brought down relative to the size of the agricultural economy. The expansion of rural credit was arrested and informal sector again trapped the poor farmers. The new strategy of agriculture growth would require more investments on infrastructure. Over the period of economic reform, agricultural growth rates slowed down significantly. The spate of farmers' suicides reported from some states reflects the distress condition of agriculture after 1991. A reversal of neo-liberal policies in agriculture has become absolutely essential to revive the livelihood systems of rural households in India.
\end{abstract}

Key words: complementarity, Capital Formation, inter-state, public investment, private investment

The economic reforms initiated in 1990-91 emphasized on "set the prices right" to boost the agriculture sector. The liberalization of the economy was anticipated to result in higher investment and growth in agriculture induced by favorable terms of trade. It was expected that the gains in terms of trade would increase investment in agriculture subsequent to the liberalisation of non agriculture sector would be more important than efficiency gains flowing from the liberalisation of agricultural trade and reduction of input subsidies. The expectations, however, did not materialize. Agricultural growth slackened and investment in agriculture, particularly on public account, declined. By the late nineties the hopefulness with respect to reforms leading to a higher investment, growth and employment in agriculture had started to weaken.

A great concern has been widely expressed by several economists that public investment in agriculture has declined in the recent years, particularly investment towards creation of irrigation potential and rural infrastructure (Dantwala,1986; Rath,1989; Misra and Chand,1995;. Shetty, 1990; Kumar,1992; Misra,1996; Alagh,1994;Gulati and Bathla,2001; Chand, 2000 and 2001; Roy and Pal, 2002; Chadha, 2003; Rao and Gulati,2005). They stressed the importance of public investment in infrastructure consisting of transport, storage, energy, etc. for the development of the agriculture sector. As such investment "for" agriculture is more relevant than investment "in" agriculture for the growth of agriculture sector.

This paper deals with the analysis of trends in investment in Indian agriculture, with specific emphasis on the period of economic reforms and divided into four sections. First, the paper describes the trends in public and private investment in Indian agriculture at constant prices with its impact on agricultural GDP (Section 1). Secondly, it extends the discussion by looking at trends in investment by explanation with quadratic equations (Section 2). Thirdly, it delineates the state level analysis of the trends in public investment and private investment in agriculture. Lastly, concluding remarks are described in Section 4.

\section{Trends in Public and Private Investment in Indian Agriculture}

In the recent years an intense debate has been waging among agricultural economists of the country about the trends in investment and the relationship between public and private investment in agriculture in the light of the declining trend in public investment in agriculture observed since the mid-eighties. The debate is mainly centered on the complementarity between public and private investment in agriculture. Both public and private investment in Indian agriculture had shown a rising trend till the end of 1970s in India. 
This led many researchers to conclude that there is a strong complementarity between public and private investment in Indian agriculture (Shetty, 1990; Mallick, 1993; Dhawan and Yadav, 1995; Gandhi, 1996). These researchers emphasized the 'crowding in' effect of public investment in agriculture in India. The opposite phenomena of a rising trend in private investment and a declining trend in public investment in agriculture observed since the 1980s has made the issue much debatable. Many scholars in recent years have challenged the operation of the 'crowding in' hypothesis of public investment in Indian agriculture (Mishra and Chand, 1995; Mishra and Hazell, 1996; Mishra, 1998).

Public investment in agriculture has played a vital role in promoting growth of agricultural output because it includes expenditures directed to agricultural infrastructure, research and development and education and training etc. It has been observed that since the beginning of 1980s gross capital formation in agriculture in public sector started coming down gradually and continued falling till early 1990s while private investment followed this declining trend only up to 1986-87, but thereafter started rising and got accelerated from 1993-94 onwards. The declining trend in public investment in agriculture in the decade of 1980s as well as in 1990s was improved since 2000-01.

On the contrary; private investment kept moving upward showing dissimilar movement in the two series since 1981-82. Ratio of gross capital formation in private sector to gross domestic product in agriculture persistently increased also with some fluctuations, while ratio of gross capital formation in public sector to gross domestic product in agriculture continuously declined in the whole period. There has been an apparent shift in the relationship of public investment and private investment in Indian agriculture in1990s and early-2000s. (Table I).

Table I-Gross Capital Formation in Public \& Private Sector in Agriculture in Relation to Gross Domestic Product in Agriculture (At 1993-94 prices) (Rs. Crore)

\begin{tabular}{|c|c|c|c|c|c|}
\hline Years & GDPag & GCFagPU & GCFagPvt. & $\begin{array}{l}\text { GCFagPU as } \\
\text { \% of GDPag }\end{array}$ & $\begin{array}{l}\text { GCFagPvt.as } \\
\text { \% of GDPag }\end{array}$ \\
\hline $1980-81$ & 159293 & 7301 & 6932 & 4.58 & 4.35 \\
\hline 1981-82 & 167723 & 7130 & 6949 & 4.25 & 4.14 \\
\hline $1982-83$ & 166577 & 7092 & 7437 & 4.26 & 4.46 \\
\hline 1983-84 & 182498 & 7196 & 7529 & 3.94 & 4.13 \\
\hline 1984-85 & 185186 & 6921 & 8027 & 3.74 & 4.33 \\
\hline $1985-86$ & 186570 & 6213 & 7919 & 3.33 & 4.24 \\
\hline $1986-87$ & 185363 & 5864 & 7844 & 3.16 & 4.23 \\
\hline $1987-88$ & 182899 & 6045 & 8204 & 3.31 & 4.49 \\
\hline \begin{tabular}{|l|}
$1988-89$ \\
\end{tabular} & 211184 & 5699 & 9063 & 2.70 & 4.29 \\
\hline $1989-90$ & 214315 & 4972 & 8452 & 2.32 & 3.94 \\
\hline \begin{tabular}{|l|}
$1990-91$ \\
\end{tabular} & 223114 & 4992 & 11424 & 2.24 & 5.12 \\
\hline 1991-92 & 219660 & 4376 & 10589 & 1.99 & 4.82 \\
\hline 1992-93 & 232386 & 4539 & 11602 & 1.95 & 4.99 \\
\hline \begin{tabular}{|l|}
$1993-94$ \\
\end{tabular} & 241967 & 4918 & 10331 & 2.03 & 4.27 \\
\hline 1994-95 & 254090 & 5397 & 11388 & 2.12 & 4.48 \\
\hline $1995-96$ & 251892 & 4849 & 10841 & 1.93 & 4.30 \\
\hline \begin{tabular}{|l|}
$1996-97$ \\
\end{tabular} & 276091 & 4668 & 11508 & 1.69 & 4.17 \\
\hline $1997-98$ & 269383 & 3979 & 11963 & 1.48 & 4.44 \\
\hline 1998-99 & 286094 & 3870 & 11025 & 1.35 & 3.85 \\
\hline \begin{tabular}{|l|}
$1999-00$ \\
\end{tabular} & 286983 & 4756 & 13083 & 1.66 & 4.56 \\
\hline $2000-01$ & 286666 & 4435 & 12980 & 1.55 & 4.53 \\
\hline $2001-02$ & 305263 & 5488 & 12250 & 1.80 & 4.01 \\
\hline $2002-03$ & 283393 & 4760 & 13881 & 1.68 & 4.90 \\
\hline $2003-04$ & 310611 & 5923 & 15261 & 1.91 & 4.91 \\
\hline 2004-05 & 310486 & 6051 & 19668 & 1.95 & 6.33 \\
\hline $2005-06$ & 329168 & 6385 & 22424 & 1.94 & 6.81 \\
\hline
\end{tabular}

Source: National Account Statistics 2000, 2001(Back Series 1950-51 to 1992 -93) 2004, 2005 and 2007 , C.S.O., Government of India, 
Chart. 1: Ratio of GCF and GFCF in Public \& Private Sector in Agriculture to GDPag

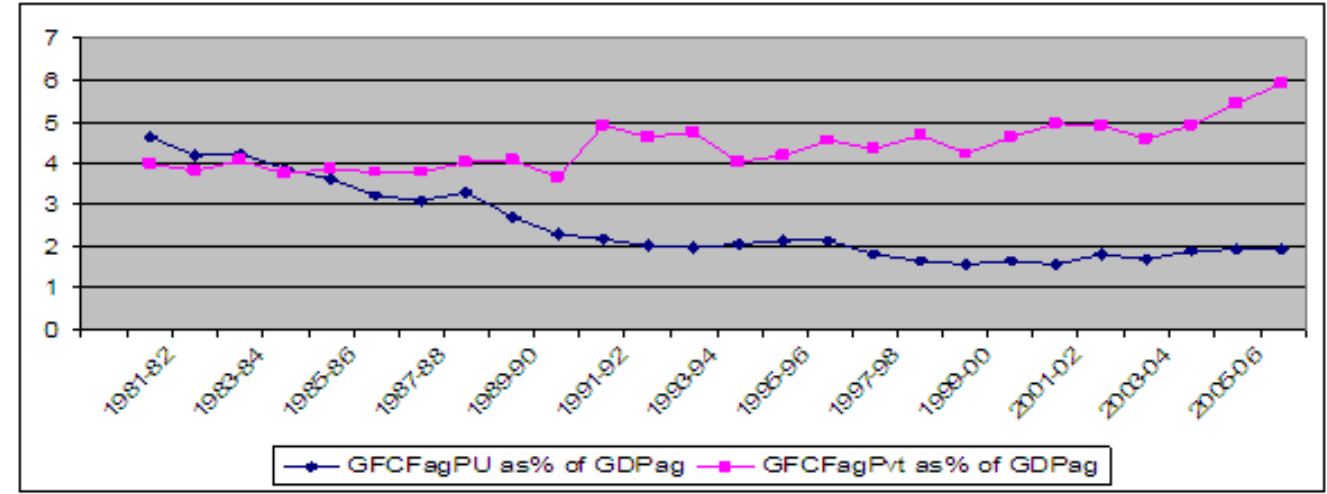

Table II: Compound Annual Growth Rate (\%) (At 1993-94 prices)

\begin{tabular}{|l|l|l|l|l|l|}
\hline Periods & GDPag & GCFagPU & GCFagPvt. & GFCFagPU & GFCFagPvt. \\
\hline $1980-81$ to $1989-90$ & 3.35 & -4.18 & 2.23 & -4.39 & 2.31 \\
\hline $1990-91$ to $1999-00$ & 2.84 & -1.85 & 1.52 & -0.25 & 2.22 \\
\hline $2000-01$ to 2005-06 & 2.80 & 7.56 & 11.55 & 7.14 & 6.56 \\
\hline $1980-81$ to 2005-06 & 2.95 & -0.53 & 4.81 & -0.61 & 4.56
\end{tabular}

The annual compound growth rates of gross capital formation and gross fixed capital formation in public sector were negative during 1980s and 1990s. On the contrary, the annual compound growth rates of gross capital formation and gross fixed capital formation in private sector show a high rate of growth during the period 1980-81 to 2005-06 (Table II). Private capital formation grew at a substantially higher rate and compensated the fall in the public sector capital formation. But the deceleration in rate of increase in private capital formation in agriculture during 1990s as compared to 1980s was quite notable, which provide a strong support to complementarity between capital formation in public and private sector in agriculture. The declining growth rate of GDP in agriculture during the period due to declining public investment was also the cause of serious concern.

The falling public investment in agriculture during the 1980 was mainly because of a large proportion of the resource flows to the agriculture sector going in to current expenditure on subsidies for fertilizers, irrigation, electricity, credit and other agricultural inputs, rather than investment. The rising level of subsidies in agriculture and diversion of funds from irrigation to anti poverty programmes were the real hindrances in the growth of public capital formation according to many scholars (Malliick, 1993, Rao, 1994, Gulati and Narayanan 2003). Hardening resources and increasing pressure on revenue expenditure in payments of salaries and interest have crowded out capital expenditure in public account since 1980s. The deteriorating trend in central tax-GDP ratio started right from the mid 1980s was a major source of fiscal imbalances (Ahluwalia 2000; Rao, 2002).

This fiscal crisis has negative impact on public investment of economy, particularly in agriculture sector. Public investment in agriculture began to decline in the 1980s, but initially the decline was offset by the fact that private investment in agriculture was increasing. Since the mid 1990s private investment in agriculture has stagnated while public investment has continued to decline. It is essential to reverse these trends, especially for public investment in irrigation and water resource management. It is also essential to increase public investment in rural roads and rural electrification. Success in these areas will stimulate private investment and contribute to a revival of growth momentum in agriculture. 


\section{Growth Rate of Public and Private Investment in Agriculture: Statistical Analysis}

Chart-2: Trends in GCF, Public and Private Investment in Agriculture at Constant Price

GCFag

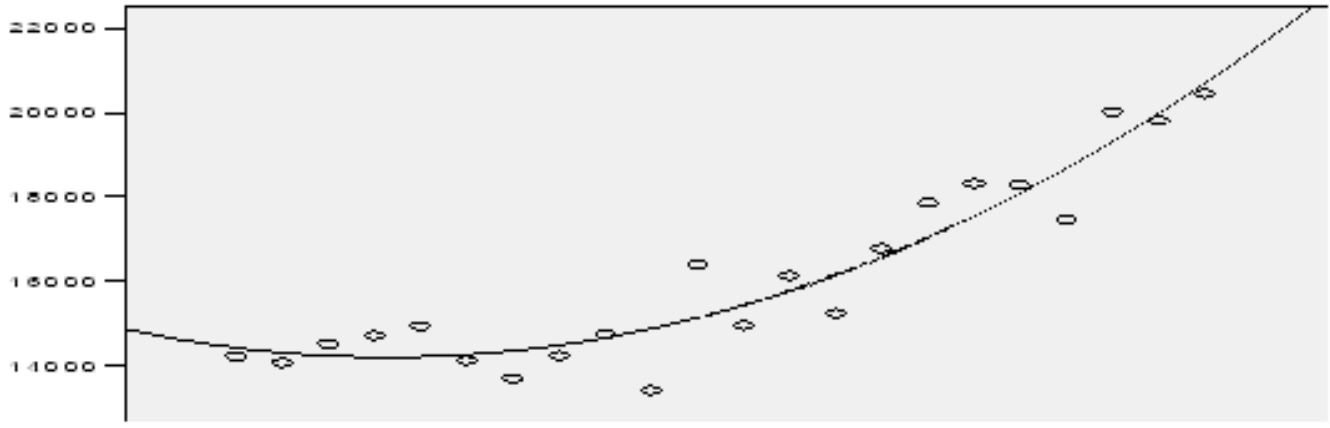

GCFpb
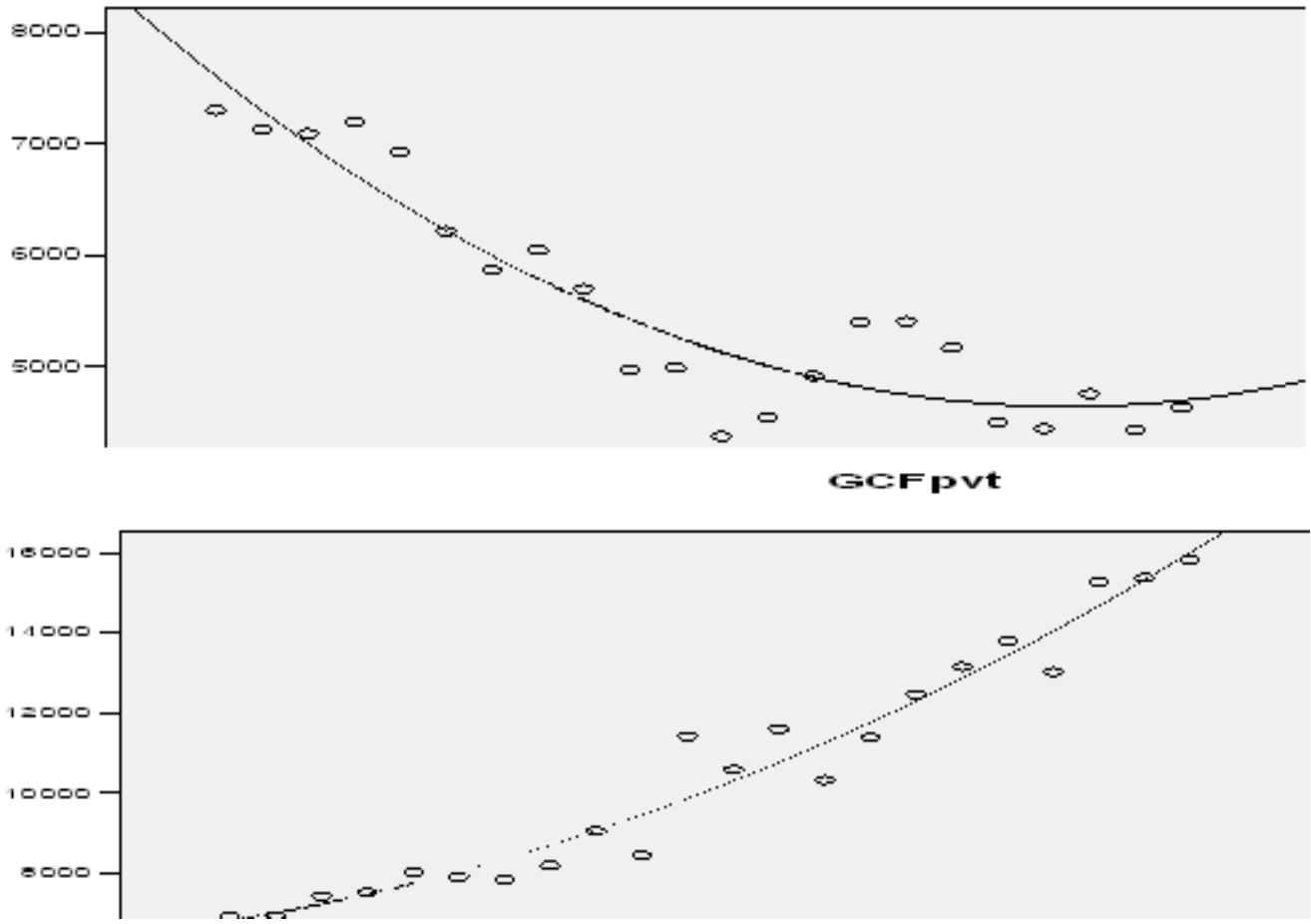

A look at the scatter plot of the data of gross capital formation in agriculture in public as well as in private sector and gross capital formation in agriculture suggests that the growth movement is non-linear. Thus, linear growth functions do not give a true picture of the trends in capital formation in agriculture.

So in this section quadratic growth equation has been estimated to explain non-linear trends in growth of gross capital formation in agriculture, gross capital formation in agriculture in public sector and in private sector. Nonlinear regression is a method of finding a non-linear relationship between the dependent variable and a set of independent variables. The relationship is second-order polynomial. That is, $\mathrm{Y}$ is a function of both $\mathrm{X}$, and of $\mathrm{X}$ squared $\left(\mathrm{X}^{*} \mathrm{X}\right)$, with the two terms having different weights (b1 and $\left.\mathrm{b} 2\right)$. This is also known as the quadratic function.

The quadratic regression function can be depicted as below:

$\mathrm{Y}=\mathrm{a}+\mathrm{b}_{1}(\mathrm{X})+\mathrm{b}_{2}\left(\mathrm{X}^{2}\right)$

Accordingly, as $\mathrm{X}$ increases, $\mathrm{Y}$ increases up to some threshold. But beyond the critical point the relationship reverses itself. If "b1" was positive, and "b2" was negative, the curve would be "parabolic," but would have downward. That is, as $\mathrm{X}$ increases, $\mathrm{Y}$ increases for a time. After the threshold, however, increases in $\mathrm{X}$ result in decline in Y. If "b1" was negative, and "b2" was positive, the curve would also be "parabolic," but would open upward. That is, as $\mathrm{X}$ increases, $\mathrm{Y}$ declines for a time. Once $\mathrm{X}$ passes the threshold, however, increases in $X$ result in increases in $Y$ (Hannemen, 2003).

The estimated quadratic regression functions are:

GCFag $=14590.71-177.36 t+20.68 t^{2}$ 


$$
\mathrm{GCFpb}=7936.49-337.72 \mathrm{t}+8.66 \mathrm{t}^{2}
$$

$$
\text { GCFpvt }=6654.21+160.37 \mathrm{t}+12.02 \mathrm{t}^{2}
$$

It was notable that the coefficient for the first term is negative and that the coefficient for the squared term is positive for all dependent variables. Over time the level of GCFag and GCFpb decreases at first but then turns positive beyond the threshold. Now we can determine the threshold value. This is the point where the first derivative of the regression function is zero. For the 2nd order polynomial, this value is b1/-2(b2). The value of "threshold" or "turning point" of the quadratic growth function was 4.29 for GCFag and 19.51 for GCFpb in agriculture. These threshold values indicate that upto 1983-84, the GCFag declined. Beyond that point the GCFag increases. GCFpb in agriculture declined upto 1998-99 and after that point it moved upwards.

\section{State-wise Trends in Public and Private Investment in Agriculture}

Capital formation at state level assumes dominant importance in the context of policy making and balanced regional development by economists. Public investment in agriculture is also the accountability of the States, but many States have neglected investment in infrastructure for agriculture. There are many rural infrastructure projects, which have started but are lying incomplete for want of resources. The overall public expenditure on agriculture is dependent on the resources available to the States, which has declined in all the states over a period of years.

\section{III.1 Public Investment}

The trends in capital expenditure on agriculture and allied heads from public account in major states at constant prices (1993-94 Prices) are presented in Table III.

The investment series at 1993-94 prices have been prepared by deflating the current price series by implicit price deflator used by the CSO for capital formation in agriculture sector. For the sake of clarity, the study have classified the entire period into five sub periods coinciding with the phases of agricultural development and declining public expenditure by states.

The data series are grouped in five years and divided in five sub periods as:

I- $\quad(1980-81$ to $1984-85)$,

II- (1985-86 to 1989-90),

III- (1990-91 to 1994-95),

IV- (1995-96 to $1999-2000)$,

V- (2000-01 to 2004-05).

Major state wise Capital expenditure on agriculture at constant prices (at 1993-94 prices) showed a different scenario. Government capital expenditure in Andhra Pradesh and Maharashtra has continuously increasing in all the sub periods while declining trend can be seen in Haryana, Himachal Pradesh, Orissa, Madhya Pradesh and Uttar Pradesh till the third period of 1990-91 to 1994-95.

Table III: Average Capital Expenditure on Agriculture and Allied Heads At Constant Prices, (1993-94 prices)

\section{Rs. Crore/year}

\begin{tabular}{|l|l|l|l|l|l|}
\hline States & $\begin{array}{l}1980-81 \text { to } \\
1984-85\end{array}$ & $\begin{array}{l}1985-86 \\
1989-90\end{array}$ & $\begin{array}{l}1990-91 \text { to } \\
1994-95\end{array}$ & $\begin{array}{l}1995-96 \text { to } \\
1999-2000\end{array}$ \\
\hline Andhra Pradesh & 388 & 392 & 509 & 539 & $12004-05$ \\
\hline Assam & 119 & 147 & 105 & 106 & 241 \\
\hline Bihar & 395 & 491 & 273 & 298 & 624 \\
\hline Gujarat & 384 & 272 & 466 & 899 & 866 \\
\hline Haryana & 189 & 133 & 111 & 184 & 306 \\
\hline Himachal Pradesh & 46 & 35 & 21 & 32 & 45 \\
\hline Jammu \& Kashmir & 176 & 215 & 105 & 98 & 193 \\
\hline Karnataka & 328 & 267 & 448 & 654 & 1031 \\
\hline Kerala & 152 & 106 & 131 & 371 & 135 \\
\hline Madhya Pradesh & 545 & 518 & 453 & 1326 & 689 \\
\hline Maharashtra & 1233 & 1314 & 1330 & 349 & 2156 \\
\hline Orissa & 330 & 225 & 216 & 365 & 294 \\
\hline Punjab & 738 & 370 & 421 & 503 & 332 \\
\hline Rajasthan & 270 & 217 & 311 & 175 & 463 \\
\hline Tamil Nadu & 122 & 110 & 118 & 544 & 337 \\
\hline Uttar Pradesh & 764 & 624 & 532 & 165 & 880 \\
\hline West Bengal & 146 & 110 & 4845 & 213 \\
\hline All India & 7033 & 5678 & \\
\hline
\end{tabular}

Source: (calculated) from RBI, Various Issues 
Chart 3: Average Capital Expenditure on Agriculture and Allied Heads at Constant Prices, (1993-94 prices) Rs. Crore/year

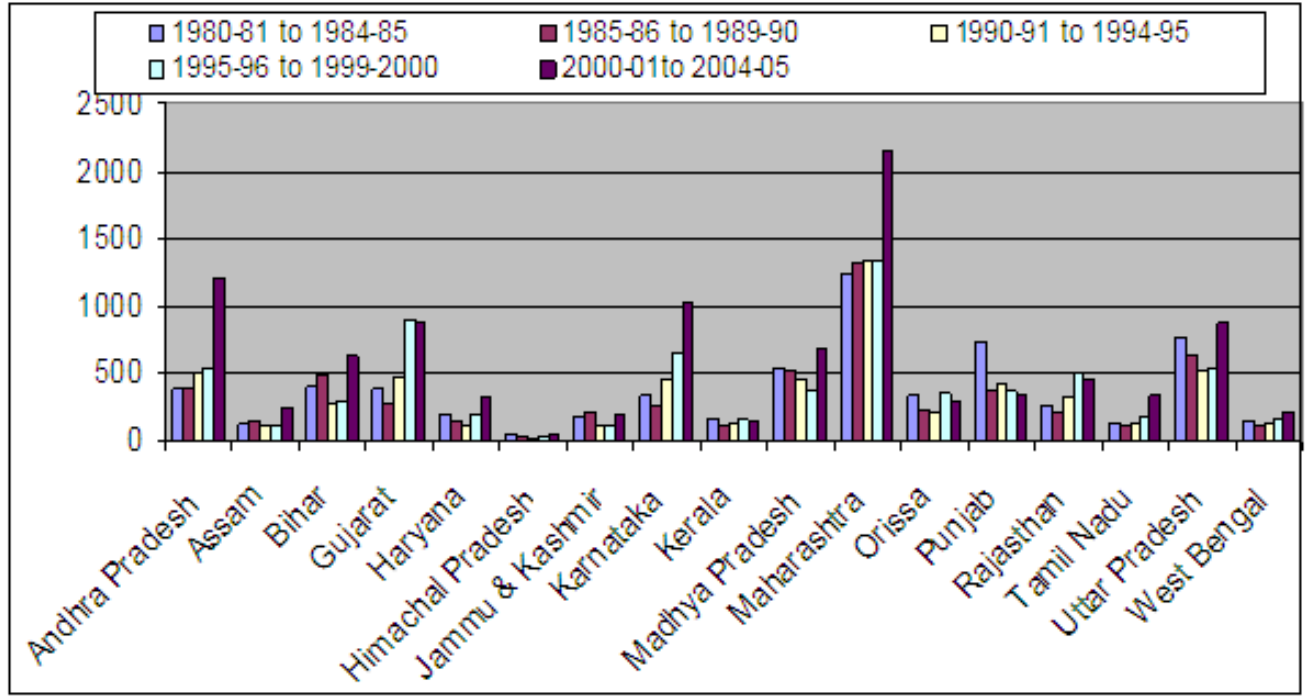

The decline was very sharp during II and III period for all states except Andhra Pradesh and Maharashtra. The decline continued during the IV period in Jammu \& Kashmir. Average Capital expenditure on agriculture in Assam, Bihar and Uttar Pradesh remained nearly stagnated during III and IV periods. Capital expenditure dropped sharply during II period in southern and western states like Kerala, Karnataka, Tamil Nadu, Gujarat, and Rajasthan. In Punjab, annual investment declined continuously from I period excluding III periods. The investment pattern in Punjab seems to be highly affected by the rise of militancy movement in the state. Public investment in the state was severally curtailed during late 1980s and early 1990s with the rise of militancy, as more and more resources were diverted to control the militancy movement (Chand, 2000).

\section{III.1.1- Per Hectare Public Investment}

Capital expenditure was computed on per hectare basis also to evaluate the relative position of different states by dividing total capital expenditure at constant prices (1993-94 prices) by net sown area of the states. Among major states capital expenditure on agriculture remained highest in Jammu and Kashmir in all the five periods. As this state have the benefit of special status in the country, it has been receiving special aid for various agricultural development schemes (Chand 2000).

Variation in per hectare annual expenditure incurred on capital formation in agriculture by different states show not any consistent trend in per hectare capital expenditure for agriculture in most of the states. Punjab Gujarat and Maharashtra allocated highest resources to development for agriculture during different periods. Per hectare public capital invested in agriculture was lowest in Rajasthan during the entire period. Other states with low per hectare investment are Tamil Nadu, Rajasthan, Uttar Pradesh and West Bengal.Punjab shows steep fall in capital expenditure since I period. Madhya Pradesh, Orissa and West Bengal has also been spending not only lesser resources but nearly stagnant amount since 1999-2000, for farm infrastructure. There were two distinct patterns in Bihar - moderately rising trend since II period and very sharp fall thereafter. In Haryana per hectare public investment in agriculture followed declining trend since 1980-81 to 1984-85, which dipped to lowest level in III period of 1990-91 to 1994-95, and increased thereafter.

Table IV: State Level Capital Expenditure on Agriculture and Allied Heads as Ratio of Net Sown Area At

\begin{tabular}{|l|l|l|l|l|l|}
\hline & $\begin{array}{l}1980-81 \text { to } \\
1984-85\end{array}$ & $\begin{array}{l}1985-86 \text { to } \\
1989-90\end{array}$ & $\begin{array}{l}1990-91 \text { to } \\
1994-95\end{array}$ & $\begin{array}{l}1995-96 \text { to } 1999- \\
2000\end{array}$ & $\begin{array}{l}2000-01 \text { to } \\
2004-05\end{array}$ \\
\hline Andhra Pradesh & 351 & 365 & 482 & 513 & 1093 \\
\hline Assam & 443 & 543 & 385 & 387 & 888 \\
\hline Bihar & 492 & 646 & 365 & 402 & 839 \\
\hline Gujarat & 400 & 287 & 492 & 931 & 910 \\
\hline Haryana & 524 & 377 & 317 & 511 & 848 \\
\hline Himachal Pradesh & 807 & 609 & 359 & 572 & 811 \\
\hline Jammu \& Kashmir & 2427 & 2980 & 1435 & 1330 & 2577 \\
\hline Karnataka & 317 & 252 & 421 & 631 & 1022 \\
\hline Kerala & 696 & 483 & 584 & 716 & 611 \\
\hline Madhya Pradesh & 286 & 270 & 744 & 246 & 462 \\
\hline Maharashtra & 678 & 726 & 743 & 1223 \\
\hline
\end{tabular}


Trends of Public and Private Investment in Indian Agriculture: An Inter State Analysis

\begin{tabular}{|l|l|l|l|l|l|}
\cline { 2 - 6 } Orissa & 538 & 363 & 342 & 574 & 486 \\
\hline Punjab & 1760 & 881 & 1003 & 869 & 780 \\
\hline Rajasthan & 174 & 150 & 189 & 304 & 292 \\
\hline Tamil Nadu & 215 & 197 & 205 & 316 & 653 \\
\hline Uttar Pradesh & 442 & 362 & 319 & 324 & 524 \\
\hline West Bengal & 267 & 206 & 233 & 303 & 391 \\
\hline All India & 498 & 407 & 340 & 339 & 317 \\
\hline
\end{tabular}

Prices, Rs./Hectare Per Year

Source: (calculated) from RBI, Various Issues

Chart 4: Capital Expenditure on Agriculture and Allied Heads as Ratio of Net Sown Area at Constant Prices, Rs. /Hectare per Year

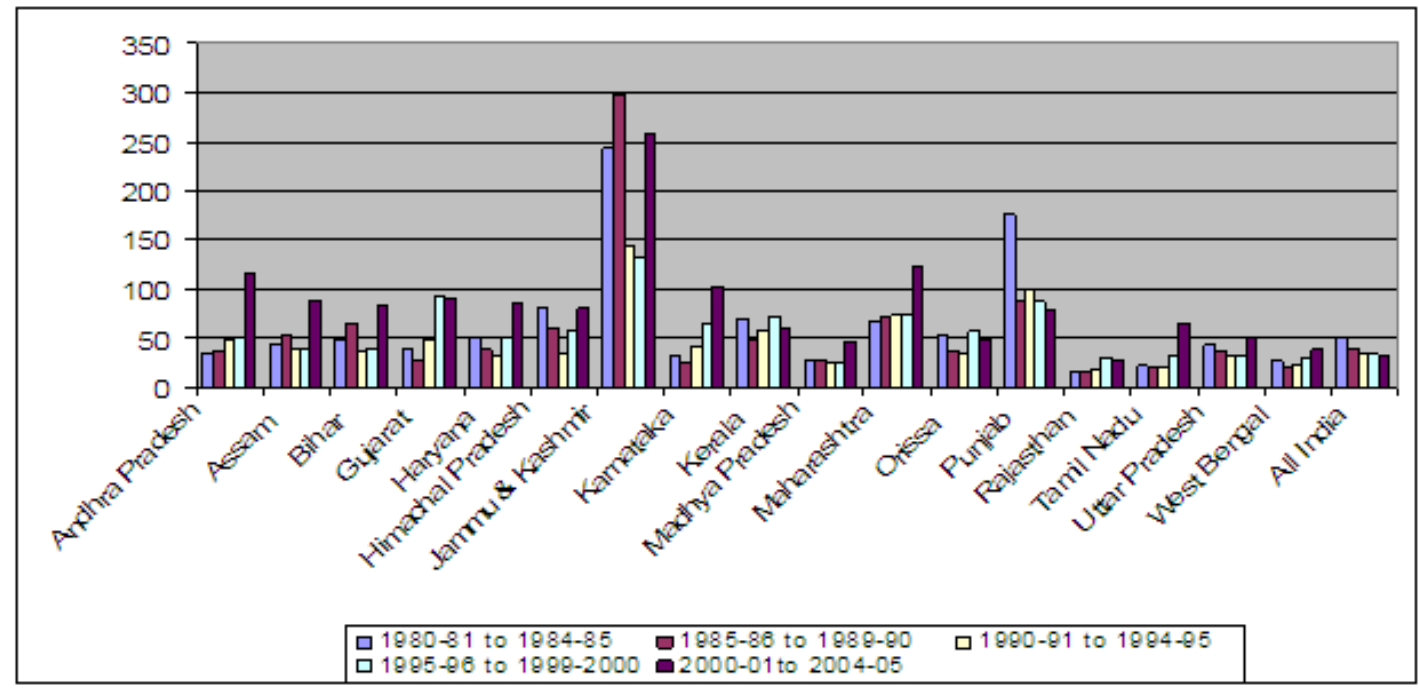

\section{III.1.2 Share of Public Investment in NSDP Agriculture}

The intensity of agricultural investment, measured as public investment in agriculture as percent of NSDPag showed a fluctuating pattern in all the states (Table V). In nine out of 17 major states in I period and seven out of 17 major states, in II and III periods, the ratio of public investment as \% of agricultural NSDP is lower than that for the country as a whole. A decline in the ratio during I to IV periods is observed for most of the states, particularly so in the case of Haryana and Punjab which is the matter of serious concern because they are the front runner states in terms of agricultural productivity. Thus there is a need for higher investment on public account to sustain the productivity level.

Table V: Capital Expenditure on Agriculture and Allied Heads as Percent of NSDPag (at Constant Prices)(1993-94 prices) Rs./year

\begin{tabular}{|c|c|c|c|c|c|}
\hline States & $\begin{array}{l}1980-81 \text { to } 1984- \\
85\end{array}$ & $\begin{array}{ll}1985-86 & \text { to } \\
1989-90 & \\
\end{array}$ & $\begin{array}{ll}1990-91 & \text { to } \\
1994-95 & \\
\end{array}$ & $\begin{array}{ll}1995-96 & \text { to } \\
1999-2000 & \\
\end{array}$ & $\begin{array}{l}2000-01 \\
\text { to } 2004-05\end{array}$ \\
\hline Andhra Pradesh & 3.1 & 3.0 & 3.2 & 3.1 & 5.5 \\
\hline Assam & 3.0 & 3.4 & 2.1 & 2.0 & 3.7 \\
\hline Bihar & 4.0 & 4.3 & 2.5 & 2.8 & 5.2 \\
\hline Gujarat & 3.8 & 3.5 & 4.5 & 6.9 & 8.4 \\
\hline Haryana & 3.7 & 2.2 & 1.4 & 2.2 & 3.1 \\
\hline Himachal Pradesh & 5.2 & 3.3 & 1.7 & 2.6 & 3.2 \\
\hline Jammu \& Kashmir & 12.7 & 15.1 & 6.0 & 4.4 & 7.6 \\
\hline Karnataka & 3.9 & 2.8 & 3.8 & 4.6 & 5.8 \\
\hline Kerala & 3.6 & 2.3 & 2.1 & 2.3 & 1.9 \\
\hline Madhya Pradesh & 6.4 & 5.3 & 3.8 & 2.5 & 4.5 \\
\hline Maharashtra & 11.1 & 10.7 & 7.8 & 6.5 & 10.6 \\
\hline Orissa & 6.0 & 3.5 & 3.8 & 5.8 & 4.9 \\
\hline Punjab & 9.6 & 3.7 & 3.4 & 2.7 & 2.1 \\
\hline Rajasthan & 3.6 & 2.8 & 2.8 & 3.6 & 3.4 \\
\hline Tamil Nadu & 1.7 & 1.3 & 1.0 & 1.3 & 2.0 \\
\hline Uttar Pradesh & 3.6 & 2.6 & 1.9 & 1.7 & 2.6 \\
\hline West Bengal & 1.8 & 1.0 & 0.9 & 0.9 & 1.1 \\
\hline All India & 4.1 & 2.9 & 2.1 & 1.8 & 1.5 \\
\hline
\end{tabular}


Chart-5: Capital Expenditure on Agriculture and Allied Heads as Percent of NSDPag (at constant prices) (1993-94 prices) Rs. /year

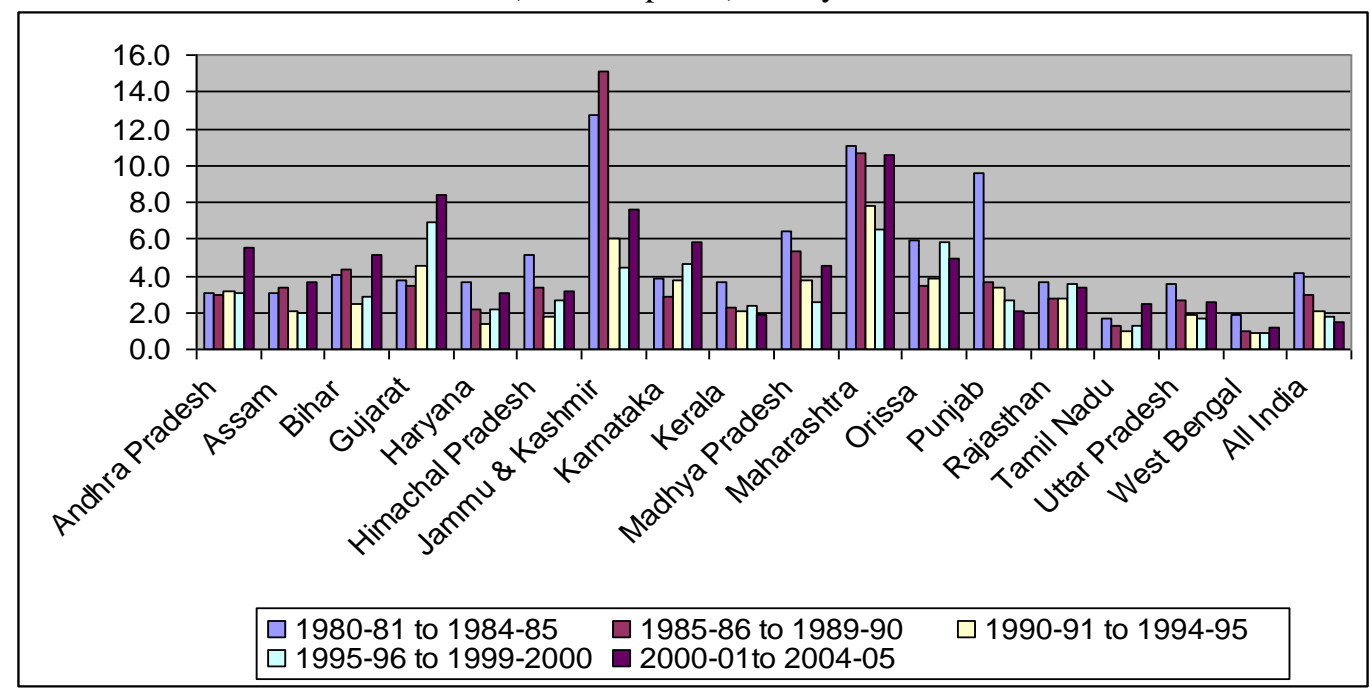

Besides Maharashtra and Jammu and Kashmir, agricultural investments as percent of NSDPag in Gujarat on public account increased continuously during II period to V period. Assam and Andhra Pradesh invested less than 3.5 percent of agricultural NSDP for capital formation in agriculture during I to IV period. Haryana is agriculturally progressive state; its allocation of NSDP agriculture to farm investment remained lower than the national average in percent term during I to III periods.

West Bengal remained at the bottom throughout in respect of agricultural investment as percent of NSDPag. In Bihar, share of public investment in agricultural NSDP dropped from during III and IV periods. At all India level, 4.1 percent of net domestic product from agriculture sector was invested for capital formation in agriculture by public sector during the first five years of decade of 1980s. However, during the second half of 1980s public resources spent for agricultural infrastructure declined to 2.9 percent of net domestic product from agriculture and the decline continued during 1990s.

\section{III.1.3 Share of Public Investment in Total NSDP}

The table reveals a depressing picture about public investment in agriculture sector by states. For the country as a whole, only about 0.5 percent of national income was ploughed back for capital formation in agriculture sector during II to V periods. Same trend can be seen from data series of state wise ratio of public capital expenditure in total NSDP. This share kept falling in all the states over time with some fluctuations. West Bengal yet again remained at the bottom throughout the periods in respect of agricultural investment as percent of NSDP total along with Tamil Nadu. Assam, Andhra Pradesh, Haryana, Himachal Pradesh, Kerala and Uttar Pradesh invested less than 1.0 percent of total NSDP for capital formation in agriculture during II to V periods.Bihar spent second highest proportion of NSDP on agricultural investment.

Table VI: Capital Expenditure on Agriculture and Allied Heads as Percent of NSDP Total (At 1993-94 prices)

\begin{tabular}{|c|c|c|c|c|c|}
\hline States & $\begin{array}{l}1980-81 \text { to } 1984- \\
85\end{array}$ & $\begin{array}{ll}1985-86 & \text { to } \\
1989-90 & \end{array}$ & $\begin{array}{ll}1990-91 & \text { to } \\
1994-95 & \\
\end{array}$ & $\begin{array}{ll}1995-96 & \text { to } \\
1999-00 & \end{array}$ & $\begin{array}{l}2000-01 \\
\text { to } 2004-05\end{array}$ \\
\hline Andhra Pradesh & 1.4 & 0.3 & 1.0 & 0.8 & 1.4 \\
\hline Assam & 1.2 & 0.2 & 0.8 & 0.7 & 1.4 \\
\hline Bihar & 2.5 & 0.5 & 1.3 & 1.2 & 2.0 \\
\hline Gujarat & 1.5 & 0.3 & 1.2 & 1.5 & 1.1 \\
\hline Haryana & 1.8 & 0.4 & 0.6 & 0.7 & 0.9 \\
\hline Himachal Pradesh & 1.8 & 0.4 & 0.5 & 0.6 & 0.6 \\
\hline Jammu \& Kashmir & 4.4 & 0.9 & 2.0 & 1.5 & 2.4 \\
\hline Karnataka & 1.6 & 0.3 & 1.3 & 1.3 & 1.5 \\
\hline Kerala & 1.1 & 0.2 & 0.6 & 0.6 & 0.4 \\
\hline Madhya Pradesh & 2.6 & 0.5 & 1.4 & 0.9 & 1.4 \\
\hline Maharashtra & 2.6 & 0.5 & 1.4 & 1.0 & 1.4 \\
\hline Orissa & 3.0 & 0.6 & 1.4 & 1.9 & 1.3 \\
\hline Punjab & 4.7 & 0.9 & 1.6 & 1.1 & 0.9 \\
\hline Rajasthan & 1.6 & 0.3 & 1.0 & 1.2 & 0.9 \\
\hline Tamil Nadu & 0.4 & 0.1 & 0.2 & 0.3 & 0.4 \\
\hline Uttar Pradesh & 1.7 & 0.3 & 0.8 & 0.6 & 0.9 \\
\hline
\end{tabular}




\begin{tabular}{|l|l|l|l|l|l|} 
West Bengal & 0.5 & 0.1 & 0.3 & 0.3 & 0.2 \\
\hline All India & 1.6 & 0.3 & 0.6 & 0.5 & 0.5 \\
\hline
\end{tabular}

Chart-6: Capital Expenditure on Agriculture and Allied Heads as Percent of NSDP Total (At 1993-94 prices)

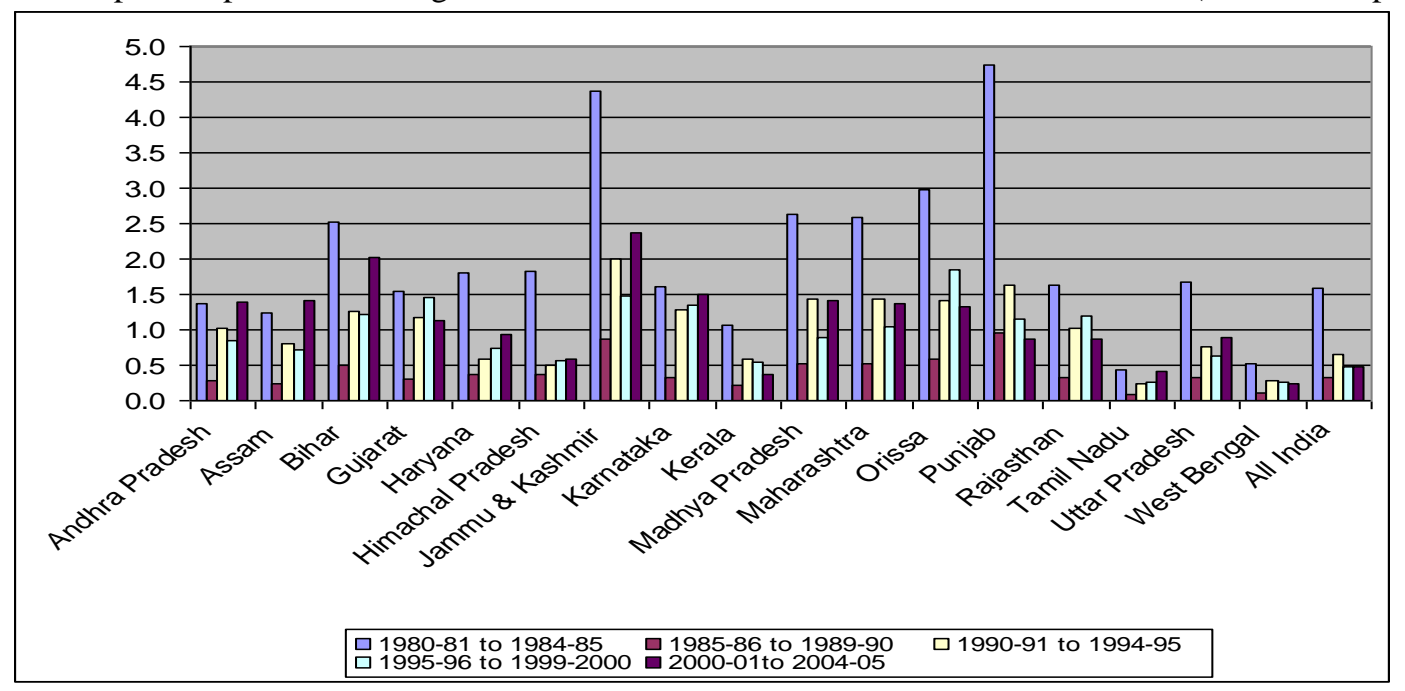

\section{III.2 Private Investment}

There are no direct data available on annual basis for compilation of capital formation in agriculture in the private sector at state level. Time series data on private investment is provided by the CSO but only at the country level. However, the RBI-NSSO have been conducting country-wide survey of debt and investment (AIDIS) at decennial intervals since 1951-52. State wise estimates of fixed capital formation in agriculture on private account at decennial intervals as revealed by RBI and NSSO surveys are presented in Table III.16 and Chart III.14.

To make inter state comparison, fixed capital formation in agriculture has been computed on per hectare of net sown area basis at 1993-94 prices for all three points of time. During 1981-82, Punjab ranked number one on the basis of private investments per hectare of net sown area at constant prices. Kerala ranked second and Haryana occupied the third place. Orissa, Assam and Bihar were at the bottom. Investment in agriculture in private account was also low in M.P., West Bengal and Rajasthan. During the years from 1981-82 to 1991-92, private investment in Orissa, Bihar, Gujarat, Andhra Pradesh and Assam further deteriorated. Madhya Pradesh marked highest growth in private fixed capital expenditure during this period. During 1991-92, Kerala has attained first position with though there was a small decline in per hectare private investment from 1981-82.

Tamil Nadu ranked second and Himachal Pradesh occupied the third place. In Punjab, Karnataka and Haryana compared to all India average Rs. 471 per hectare of net sown area in 2002-03, per hectare private investment was also quite remarkable in 1991-92. Uttar Pradesh and Maharashtra also achieved impressive growth in fixed capital formation in agriculture but private investment in Haryana and Uttar Pradesh declined from 1981-82 to 1991-92.

In Jammu \& Kashmir private investment in fixed assets in agriculture showed sharp decline Himachal Pradesh continuously performed well and occupied the first place. Haryana and Tamil Nadu were at second and third place respectively. Among other states, per hectare private investment at constant prices in Andhra Pradesh, Gujarat, Jammu \& Kashmir, Punjab and Uttar Pradesh increased from 1991-92.

While during the 11 years, from 1991-92 to 2002-03, private investment in Bihar, Karnataka, Maharashtra, Madhya Pradesh and West Bengal went down and remained below the country average. In Kerala, per hectare private investment at constant prices remained almost constant in this period. Uttar Pradesh showed improvement rising from Rs.499 in 1991-92 to Rs. 575 in 2002-03.

Table VII: State-wise Total and Per Hectare Private Capital Formation in Agriculture

\begin{tabular}{|l|l|l|l|l|l|l|}
\hline \multirow{3}{*}{ States } & \multicolumn{2}{l}{$\begin{array}{l}\text { Total FCFA } \\
\text { At Current Prices (Rs. Crore) }\end{array}$} & \multicolumn{2}{l|}{$\begin{array}{l}\text { Per Hectare of Net Sown Area } \\
\text { at 1993-94 prices }\end{array}$} \\
\cline { 2 - 8 } & $\mathbf{1 9 8 1 - 8 2}$ & $\mathbf{1 9 9 1 - 9 2}$ & $\mathbf{2 0 0 2 - 0 3}$ & $\mathbf{1 9 8 1 - 8 2}$ & $\mathbf{1 9 9 1 - 9 2}$ & $\mathbf{2 0 0 2 - 0 3}$ \\
\hline Andhra Pradesh & 110 & 283 & 684 & 362 & 307 & 347 \\
\hline Assam & 12 & 19 & 44 & 163 & 83 & 88 \\
\hline Bihar & 39 & 79 & 83 & 167 & 122 & 61 \\
\hline Gujarat & 98 & 201 & 682 & 361 & 258 & 384 \\
\hline Haryana & 82 & 169 & 761 & 802 & 577 & 1138 \\
\hline
\end{tabular}


Trends of Public and Private Investment in Indian Agriculture: An Inter State Analysis

\begin{tabular}{|l|l|l|l|l|l|l|} 
Himachal Pradesh & 7 & 36 & 132 & 429 & 753 & 1299 \\
\hline Jammu \& Kashmir & 8 & 13 & 80 & 412 & 206 & 579 \\
\hline Karnataka & 99 & 535 & 404 & 350 & 598 & 219 \\
\hline Kerala & 54 & 157 & 328 & 868 & 839 & 809 \\
\hline Madhya Pradesh & 112 & 716 & 911 & 210 & 443 & 332 \\
\hline Maharashtra & 167 & 659 & 1292 & 326 & 445 & 399 \\
\hline Orissa & 16 & 37 & 94 & 93 & 70 & 86 \\
\hline Punjab & 129 & 198 & 597 & 1080 & 563 & 766 \\
\hline Rajasthan & 99 & 499 & 1114 & 228 & 386 & 383 \\
\hline Tamil Nadu & 89 & 382 & 692 & 586 & 799 & 821 \\
\hline Uttar Pradesh & 267 & 685 & 1744 & 545 & 499 & 575 \\
\hline West Bengal & 34 & 94 & 146 & 212 & 207 & 149 \\
\hline India & 1445 & 4801 & 11622 & 363 & 406 & 471 \\
\hline
\end{tabular}

Sources: 1. RBI (1988), Household Capital Expenditure during 01.07.1981 to 30.06.1982: All India Debt \& Investment Survey 1981-82, Reserve Bank of India, Bombay

2. NSSO (1998), Household Capital Expenditure during 01.07.1991 to 30.06.1992: Debt and Investment Survey, 48th round, Ministry of Planning \& Programme Implementation, Govt. of India

3. NSSO (2005), Household Capital Expenditure during 01.07.2002 to 30.06.2003: Debt and Investment Survey, 58th round, Ministry of Planning \& Programme Implementation Govt. of India

\section{Chart-7: Private Investment per Hectare of Net Sown Area at 1993-94 Prices}

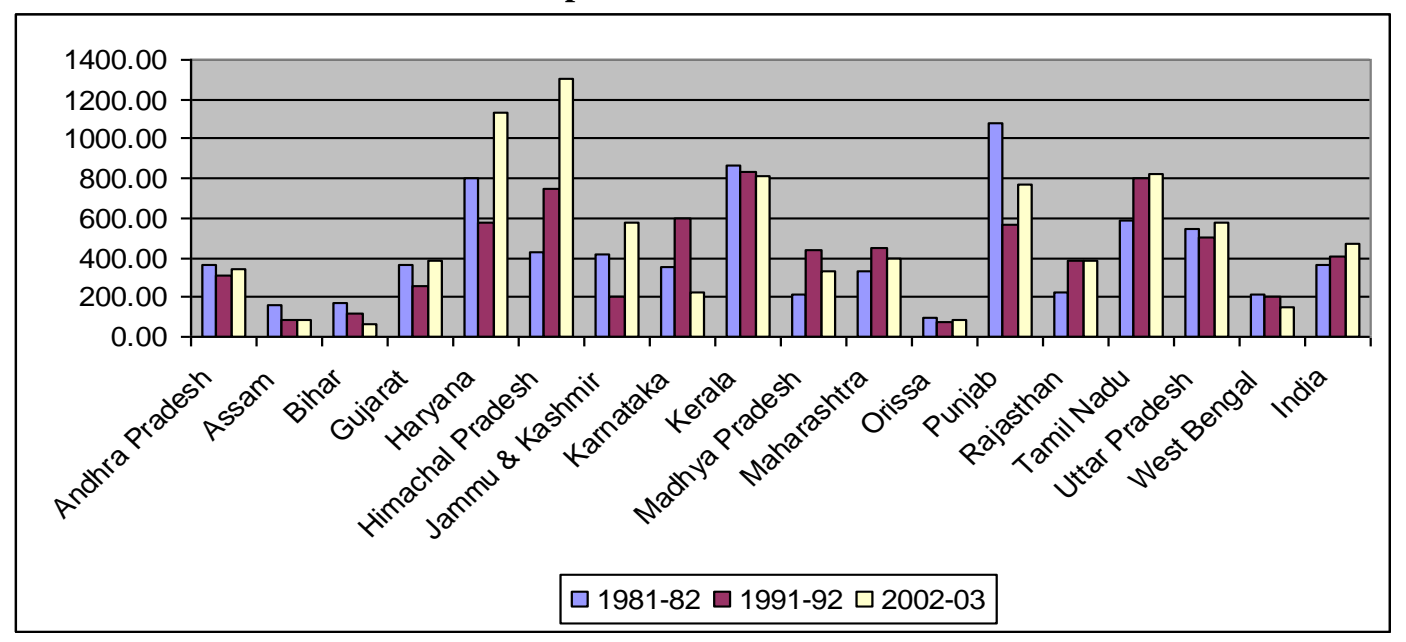

IV. Conclusion

Analysis with investment series has confirmed deceleration in public investment both at national and state level. During early phase, the share of public and private sectors in total investment was almost equal, and there has been a steady rise in the share of private investment since mid eighties. There are undeniable evidences of decline in investment in real terms after the eighties. Public investment in agriculture began to decline in the 1980 s, but initially the decline was offset by the fact that private investment in agriculture was increasing. Since the mid 1990s private investment in agriculture has stagnated while public investment has continued to decline. After 2000-01, public and private investment in agriculture moved in upward direction and revealed increasing trends. In state level analysis, declining trend of public investment in real terms across the board in most of the states since mid 1980s also has been reported. Share of GFCF in agricultural GDP was lower in 1990s than in 1980s. The falling public investment in agriculture during the 1980 was mainly because of a large proportion of the resource flows to the agriculture sector going in to current expenditure on subsidies for fertilizers, irrigation, electricity, credit and other agricultural inputs, rather than investment. Diversion of funds from irrigation to anti poverty programmes and increasing pressure on revenue expenditure in payments of salaries and interest were the real hindrances in the growth of public capital formation according to many scholars.

In Indian agriculture, which continues to provide livelihood for more than half of the population, pro developed countries' policies after 1991 had acute adverse effects. The self-sufficiency in food production after green revolution was built with government support; like price supports, credit assistance and marketing facilities, which led to the creation of a network of institutional support structures in rural areas. The reform process in India significantly weakened the structural support through declining public investment "in" agriculture as well as "for" agriculture. As part of fiscal reforms, major input subsidies were brought down relative to the size of the agricultural economy. Public capital formation in agriculture continued to fall, and the growth of public expenditure on research and extension slowed down. The expansion of rural credit was arrested 
and informal sector again trapped the poor farmers. The new strategy of agriculture growth and diversification of agriculture from traditional crop cultivation to horticulture etc. would require more investments on cold storage, rural roads, communication, marketing network and facilities, warehouses etc. Simultaneously efforts should be made to revitalize agriculture through introduction of bio-technology and other innovations. This would require substantial increase in investment on research \& development for agriculture.

Over the period of economic reform, agricultural growth rates slowed down significantly. Most importantly, the rate of growth of food grain production slowed down, and fell behind the population growth rates for the first time after independence. The spate of farmers' suicides reported from some states reflects the distress condition of agriculture after 1991. A reversal of neo-liberal policies in agriculture has become absolutely essential to revive the livelihood systems of rural households in India.

\section{References}

[1]. Ahluwalia, Montek, S (2000), "Economic Performances of States in Post Reforms Period", Economic and Political Weekly, Vol.35, May 6.

[2]. Alagh, Y.K. (1994), "Macro Policies for Indian Agriculture" in G.S. Bhalla (ed.), Economic Liberalisation and Indian Agriculture, Institute for Studies in Industrial Development, New Delhi.

[3]. Chadha (2003), "Indian Agriculture in the New Millennium: Human Response to Technology Challenges", Indian Journal of Agricultural Economics, Vol.58, No.1, January-March

[4]. Chand, Ramesh (2000), "Emerging Trends and Regional Variations in Agricultural Investments and Their Implications for Growth and Equity", Policy Paper-11, National Centre for Agricultural Economics and Policy Research, New Delhi.

[5]. Chand, Ramesh (2001), "Emerging Trends and Issues in Public and Private Investment in Indian Agriculture: A State-wise Analysis", Indian Journal of Agricultural Economics, Vol.56, No.2, April-June.

[6]. Dantwala, M.L. (1986), "Strategy of Agricultural Development Since Independence," in Dantwala, M.L. (ed.), Indian Agricultural Development Since Independence: A Collection of Essays, Oxford and IBH Publishing Co. Pvt. Ltd., New Delhi.

[7]. Dhawan, B.D. and S.S. Yadav (1995), "Private Fixed Capital Format in Agriculture: Some Aspects of Indian Farmers' Investment Behaviour", Economic and Political Weekly, Vol.30, No.30, September 30.

[8]. Gandhi, Vasant, P. (1996), "Investment Behaviour in Indian Agriculture", Indian Journal of Agricultural Economics, Vol.51, No.4, October-December.

[9]. Government of India (2000), (2004), (2005), (2007), National Account Statistics, Central Statistical Organisation, Department of Statistics, Ministry of Planning, New Delhi.

[10]. Government of India, (2001), National Account Statistics, (Back Series 1950-51 to 1992-93), Central Statistical Organisation, Department of Statistics, Ministry of Planning, New Delhi.

[11]. Government of India (2003), "Report of the Committee on Capital Formation in Agriculture", Directorate of Economics and Statistics, Department of Agriculture \& Cooperation, Ministry of Agriculture, Government of India.

[12]. Gulati, A. and S. Narayanan (2003), Subsidy Syndrome in Indian Agriculture, Oxford University Press, New Delhi.

[13]. Gulati, Ashok and Seema Bathla (2001), "Capital Formation in Indian Agriculture: Re-visiting the Debate", Economic and Political Weekly, Vol.36, No.20, May 19.

[14]. Kumar, A. Ganesh (1992), "Falling Agricultural Investment and Its Consequences", Economic and Political Weekly, Vol.27, No.42, October 17.

[15]. Mallick, Sushanta, K. (1993), “Capital Formation in Indian Agriculture: Recent Trends”, Indian Journal of Agricultural Economics, Vol.48, No.4, October-December

[16]. Misra, V.N. (1998), "Economic Reforms, Terms of Trade, Aggregate Supply and Private Investment in Agriculture: Indian Experience", Economic and Political Weekly, Vol.33, No.31, August 1

[17]. Misra, V.N. and M. Govinda Rao (2003). "Trade Policy, Agricultural Growth and Rural Poor: Indian Experience, 1978-79 to 19992000", Economic and Political Weekly, Vol.38, No.43, October 25.

[18]. Misra, V.N. and Peter, B.R. Hazell (1996), "Terms of Trade, Rural Poverty, Technology and Investment: The Indian Experience, 1952-53 to 1990-91", Economic and Political Weekly, Vol.31, No.13, March 30.

[19]. Misra, S.N. (1996), "Capital Formation and Accumulation in Indian Agriculture Since Independence", Indian Journal of Agricultural Economics, Vol.51, Nos.1\&2, January-June.

[20]. Misra, S.N. and Ramesh Chand (1995), "Public and Private Capital Formation in Indian Agriculture: Comments on the Complementarity Hypothesis and Others", Economic and Political Weekly, Vol.30, No.25, June 24.

[21]. NSSO (1998), Household Capital Expenditure During 01.07.1991 to 30.06.1992: Debt and Investment Survey, $48^{\text {th }}$ round, Ministry of Planning \& Programme Implementation, Government of India

[22]. NSSO (2005), Household Capital Expenditure during 01.07.2002 to 30.06.2003: Debt and Investment Survey, 58 ${ }^{\text {th }}$ round, Ministry of Planning \& Programme Implementation, Government of India.

[23]. Rao, C. Hanumantha (1994), Agricultural Growth, Rural Poverty and Environmental Degradation in India, Oxford University Press, Delhi.

[24]. Rao, C. Hanumantha (2001), “WTO and Viability of Indian Agriculture”, Economic and Political Weekly, Vol.36, No.3, September 8.

[25]. Rao, M. Govind (2002), "State Finances in India: Issues and Challenges", Economic and Political Weekly, Vol.37, August 3.

[26]. Rath, Neelkanth, (1989), "Agricultural Growth and Investment in India”, Journal of Political Economy, Vol.11 No.1, January-June.

[27]. Reserve Bank of India (1977), Household Capital Expenditure during 01.07.1971 to 30.06.1972: All India debt and investment survey, $38^{\text {th }}$ Round, Reserve Bank of India, Mumbai.

[28]. Reserve Bank of India (1988), Household Capital Expenditure during 01.07.1981 to 30.06.1982: All India Debt \& Investment Survey 1981-82, Reserve Bank of India, Mumbai.

[29]. Roy, B.C. and Suresh Pal (2002), "Investment, Agricultural Productivity and Rural Poverty in India: A State Level Analysis", Indian Journal of Agricultural Economics, Vol.57, No.4, October-December.

[30]. Shetty, S.L. (1990), "Investment in Agriculture: Brief Review of Recent Trends", Economic and Political Weekly, Vol.25, Nos.7\&8, February 17-24. 